\title{
End post-rigour phase Yellowstripe scad fish (Caranx leptolepis) peptones and its application for bacteria's growth media
}

\author{
1,*Saputra, D., ${ }^{2}$ Nurhayati, T. and ${ }^{2}$ Purwaningsih, S. \\ ${ }^{I}$ Department of Food Technology, Bina Nusantara University, Jl. Jalur Sutera Barat Kav. 21, Tangerang, \\ 15326, Indonesia \\ ${ }^{2}$ Department of Aquatic Product Technology, IPB University, Jl. Agatis Gedung FPIK IPB Dramaga, \\ Bogor, 16680, Indonesia
}

\begin{abstract}
Article history:
Received: 29 May 2019

Received in revised form: 30

September 2019

Accepted: 2 October 2019

Available Online: 22

October 2019
\end{abstract}

Keywords:

End post-rigour phase,

Enzymatic Hydrolysis,

Papain,

Peptones,

Yellowstripe scad fish

DOI:

https://doi.org/10.26656/fr.2017.4(2).210

\begin{abstract}
Peptones are produced from products with high protein content. Recently, peptone produced from fishery by-products were sought as a source of bacteria substrate. In this study, the enzymatic hydrolysis of peptone production of Yellowstrip scad fish at the end post-rigour phase was optimized. Peptones produced were physicochemically characterised and tested for microbial growth application. Proximate composition, peptone characterisation and amino acid analysis were conducted following AOAC methods. The $\mathrm{pH}$ value of the peptones was measured using a $\mathrm{pH}$-meter and the microbial growth was monitored via measuring the optical density (OD) of the cultures. The outcome of the research showed that the best enzymatic hydrolysis was $0.20 \%(\mathrm{w} / \mathrm{v})$ papain carried out for 6 hours. The results showed that the Yellowstripe scad fish peptones (YSFP) had a high protein level (77.46\%) and contained essential amino acids such as histidine (4.12\%), isoleucine $(0.96 \%)$, leucine $(2.42 \%)$, lysine $(2.25 \%)$, methionine $(3.07 \%)$, phenylalanine (1.68\%), threonine $(1.06 \%)$, valine $(2.61 \%)$, and arginine $(2.85 \%)$. The end post-rigour phase YSFP has a solubility of $97.08 \%$; total nitrogen of $12.39 \%$; $\alpha$-amino nitrogen of $1.03 \mathrm{~g} / 100 \mathrm{~g}$; $\alpha$-amino nitrogen per total nitrogen of 8.31 and salinity of $4.19 \%$. Bacillus spp., Staphylococcus aureus and Escherichia coli was observed to have better growth performances on the YSFP than bacto peptone.
\end{abstract}

\section{Introduction}

Indonesia has a very high potential of fishery products as raw materials of animal protein sources. The main fishery products produced are Surimi, Kamaboko, fish fillets, often with high economic value. However, there are several types of fish do not have high economic value, such as the Yellowstripe scad fish, often assigned to fishery by-products. Based on the data of Indonesian Ministry of Maritime Affairs and Fisheries (KKP, 2011), Yellowstripe scad fish production has increased up to 23.230 metric tons, i.e. from 156.710 metric tons in 2009 to 179.940 metric tons in 2010. There was an increasing volume production of Yellowstripe scad fish in the North Sumatra Province. During that time, the fishes were wasted at the fish landing sites or simply processed into non-food products like animal feeds and non-economic by-products such as fish silage, protein concentrates, etc.

Fishery by-products can be used to produce fish peptones. Fish peptone is a product that has high economic value in the fishery sector due to the high market price compared to other fishery by-products such as fish oil, fish silage, and fish powder. Peptones are hydrolysates protein that contains peptides and free amino acids which are heat stable and water-soluble reported by (Green et al., 1977; Vaseliva-Tonkova et al., 2007). Peptone can be generated through the hydrolysis processes of acid, alkaline or enzyme (raw materials, photolytic, fish-derived, etc.) and using microbes deriving protease (Kristinsson and Rasco, 2000).

Indonesia has been importing peptone from other countries at a high price and it has been increasing each year. Voigt Global Distribution Inc. (2019) reported the purchase of bacto peptone $500 \mathrm{~g}$ was USD 122.50. This calls for a need to research for substitutes of bacto peptone. Saputra (2008) and Saputra and Nurhayati (2013) reported that the fishery by-product in the postrigour state has a good potential to be used as a raw material in the bacteria medium. Falah et al. (2015) reported that the growth of Staphylococcus aureus on the medium which uses Silver carp fish peptone hydrolysed with Alcalase enzyme was better than Tryptic Soy Broth 
and trypsin medium. Vieira et al. (2005); Safari et al. (2011); and Safari et al. (2012) also compared fish peptones with commercially available peptones and reported positive reviews.

The purpose of this study was to optimize the enzymatic hydrolysis of YSFP production at the end post -rigour phase and to test the YSFP for microbial growth application. The YSFP produced at different enzyme concentrations were characterized and evaluated.

\section{Materials and methods}

\subsection{Raw materials}

Yellowstripe scad fish (Caranx leptolepis) was received from Muara Baru, West Jakarta and kept at 4$10^{\circ} \mathrm{C}$ before processing. Bacillus spp., S. aureus, and Escherichia coli were received from Food Microbiology Laboratory in SEAFAST Center, Indonesia. The enzyme used was commercial local crude papain enzymes received from PAU Biochemistry laboratory located in IPB University. All chemicals and reagents used in this work were analysis grade for chemical, biochemical, and microbiology tests such as sulfuric acid $\left(\mathrm{H}_{2} \mathrm{SO}_{4}\right)$, hydrochloric acid $(\mathrm{HCl})$, potassium hydroxide $(\mathrm{KOH})$, sodium hydroxide $(\mathrm{NaOH})$, sodium thiosulfate $\left(\mathrm{Na}_{2} \mathrm{~S}_{2} \mathrm{O}_{3}\right)$, boric acid $\left(\mathrm{H}_{3} \mathrm{BO}_{3}\right)$, acetonitrile, nutrient broth (NB) (DIFCO 234000), commercial peptones (bacto peptone) (DIFCO 234000).

\subsection{Peptone production}

The preparation of fish peptone was performed according to previous studies by Saputra (2008) and Saputra and Nurhayati (2013). Yellowstripe scad fish (Caranx leptolepis) at the end post-rigour phase was cut to $2 \times 2 \mathrm{~cm}$ size. The cut samples were mixed with distilled water $(1: 2 \mathrm{w} / \mathrm{v})$ and added with papain enzymes at concentrations of $0 \%$ (control); $0.02 \% ; 0.08 \% ; 0.14 \%$; $0.20 \% ; 0.26 \%$; and $0.32 \%(\mathrm{w} / \mathrm{v})$. The experiment was performed in duplicate. The mixture was incubated at $60^{\circ} \mathrm{C}$ in the hot shaker bath (B-Braunc) at the natural $\mathrm{pH}$ for 2,4 , and 6 hrs. The $\mathrm{pH}$ values of the mixture were determined before incubation $(0 \mathrm{hr})$ and at two-hour intervals. After $6 \mathrm{hrs}$, the papain enzymes were inactivated by heating the mixture to $85^{\circ} \mathrm{C}$ for 15 mins. The sediment was separated from the supernatant and was kept at $4-10^{\circ} \mathrm{C}$ for $24 \mathrm{hrs}$ in the chiller until the lipid on the surface of supernatant appears. Then, the lipid on the supernatant was discarded. The supernatant was spray-dried (Inlet temperature: $170^{\circ} \mathrm{C}$; Outlet temperature: $70^{\circ} \mathrm{C}$ ) and referred to as YSFP.

\subsection{Chemical composition}

The proximate composition (moisture, ash, crude protein and crude lipid) of the Yellowstripe scad fish at the end post-rigour phase as the raw material and the peptones were conducted following the AOAC (2005) methods. The total nitrogen content of the YSFP was determined by the Kjeldahl method (AOAC, 2005). The ratio of Total Solubility Nitrogen (TSN) to Total Nitrogen Raw Material (TNRM) of the YSFP was estimated as per (AOAC, 2005) method to determine the best enzyme concentration. All analysis was performed in triplicate.

\subsection{Characterization of the Yellowstripe scad fish peptone}

Characterization parameters used were solubility in water (Gravimetric analysis); total nitrogen (TN) (AOAC, 2005) method; $\alpha$-amino nitrogen $(\alpha / \mathrm{N})$ (AOAC, 1995) method; $\alpha$-amino nitrogen/total nitrogen $(\alpha / \mathrm{N}) /$ TN; and salinity based on Volhard method (United States Department of Agriculture (USDA) Food Safety and Inspection Service (FSIS), 2009). YSFP were compared with commercially available bacto peptone from Difco, used as the standard, and post-rigour Yellowstripe scad fish peptone (Saputra, 2008; Saputra and Nurhayati, 2013).

\subsection{Amino acid analysis}

The amino acid analysis was performed on two types of bacto peptone (Oxoid and Difco), post-rigour Yellowstripe scad fish and the end post-rigour phase YSFP. The end post-rigour phase YSFP with the highest TSN/TNRM ratio was selected. The amino acid composition was determined following the AOAC (2000) method where the samples were hydrolyzed with $6 \mathrm{~N} \mathrm{HCl}$ (amino acids other than cysteine, methionine, and tryptophan). Then, the free amino acids were separated using the High-Performance Liquid Chromatography (HPLC). The identity and quantity of the amino acids were determined by a comparison between the retention times and peak areas of each amino acid standard.

\subsection{Microbial growth application}

The strains of Bacillus spp., S. aureus, and E. coli were used to test the microbial growth performance. The inoculum was prepared by inoculating each strain into $100 \mathrm{~mL}$ of NB and incubated in the shaker incubator at $30^{\circ} \mathrm{C}$ for $18 \mathrm{hrs}$. The media was prepared by adding $5 \%$ $(\mathrm{v} / \mathrm{v})$ of peptone into NB (Rahayuningsih and Wiranti, 2014). In this analysis, the end post-rigour phase YSFP, bacto peptone (Difco) and post-rigour Yellowstripe scad fish peptone was tested as subjects. An aliquot $(1 \mathrm{~mL})$ of the inoculum was inoculated into the prepared media. The microbial growth was monitored by measuring the 
optical density (OD) of the cultures using a spectrophotometer UV 1800 (Shimadzu). The bacterial density in the different media was determined by measuring the turbidity at two-hour intervals, for $20 \mathrm{hrs}$. The OD was performed by shaking the culture for $5 \mathrm{~s}$ before withdrawing $2.5 \mathrm{~mL}$ of the culture and read at 660 $\mathrm{nm}$ (Poernomo and Buckle, 2002). A growth curve of OD against the incubation time (semilog) was constructed. The straight and steep segment of the curve where the correlation between time and log OD was linear, was considered the exponential growth phase. The slope $(\log A / h)$ of the exponential growth phase curve was taken as the growth rate.

\subsection{Statistical analysis}

Data (means) was subjected to one-way analysis of variance (ANOVA) (Herzog et al., 2019) with Least Significant Different test (LSD) test using SPSS IBM 20.0 to evaluate the statistical significance. All data are presented as mean $\pm \mathrm{SD}$, while for the chemical composition of the raw material and final product were analyzed with descriptive statistics.

\section{Results and discussion}

\subsection{Chemical composition of Yellowstripe scad fish}

As shown in Table 1, the proximate composition of the end post-rigour phase Yellowstripe scad fish are as follows: moisture content (75.71\%); ash (2.31\%); protein content (15.47\%); and lipid content (2.94\%). All chemical composition was measured on a wet mass basis in the $\mathrm{g} .100 \mathrm{~g}^{-1}$ raw material.

Table 1. Chemical composition of the Yellowstripe scad fish (Caranx Leptolepis)

\begin{tabular}{cc}
\hline Parameter & $(\%)^{*}$ \\
\hline Moisture & 75.71 \\
Ash & 2.31 \\
Protein & 15.47 \\
Lipid & 2.94 \\
\hline
\end{tabular}

* Values (means) are expressed as a percentage (g. $\left.100 \mathrm{~g}^{-1}\right)$ on a wet mass basis.

Based on the results, it can be concluded that the Yellowstripe scad fish has the potential to be used as raw material to produce fish peptones because it has a high protein content with low lipid content. This result agrees with the findings of Saputra and Nurhayati (2013) reported that the post-rigour Yellowstripe scad fish was a potential material to produce fish peptones, with the protein content of $64.27 \%$ and lipid content of $12.10 \%$. This was further supported by the report of Nurhayati et al. (2015), in which the chemical composition of spoiled by-catch fish has a protein content of $15.56 \%$, moisture content of $70.90 \%$, an ash content of $5.36 \%$, and fat content of $3.06 \%$.
Figure 1 depicts the TSN/TNRM ratio over the enzyme concentration. Overall, the results showed that the TSN/TNRM ratio increased as the enzyme concentration increases. Enzyme concentration at $0.20 \%$ produced the highest TSN/TNRM ratio $(0.32 \%)$ and was selected as the best enzyme concentration of the enzymatic hydrolysis. Moreover, the ratio showed a statistically significant difference $(p<0.05)$ than other ratios. In the study conducted by Saputra and Nurhayati (2013), $0.26 \%$ of papain enzyme concentration was selected to hydrolyse the post-rigour Yellowstripe scad fish peptones. The similar results were observed in the study by Suhandana (2010) whereby the same papain enzyme concentration was used to hydrolyse yellowfin tuna viscera.

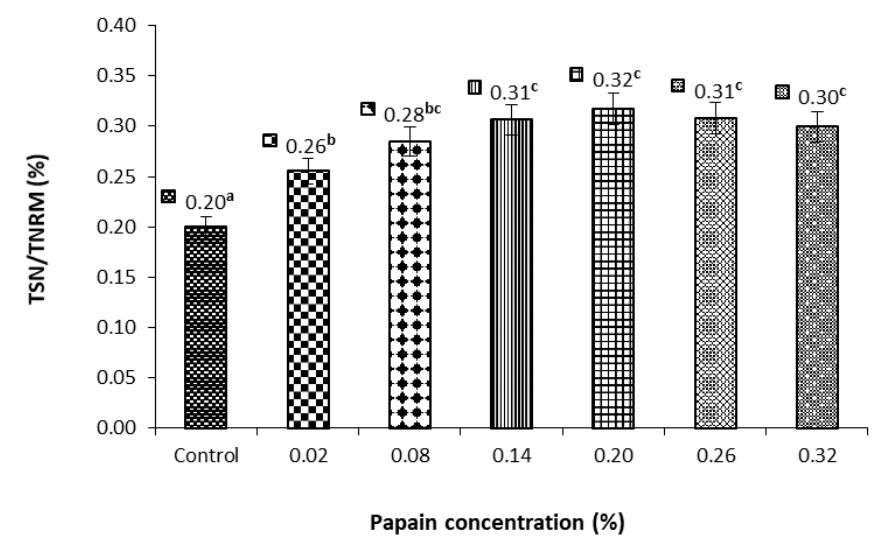

Figure. 1. The average value of TSN/TNRM of hydrolysates with different papain enzyme concentrations. Different superscripts in the curves indicate significant differences $(\mathrm{p}<0.05)$

\subsection{Chemical composition of end post-rigour phase Yellowstripe scad fish peptones}

The chemical composition of end post-rigour phase YSFP is shown in Table 2. From the result, it can be inferred that the crude protein content of the end postrigour phase YSFP was $83.62 \pm 1.05 \%$, lipid content was $0.07 \pm 0.01 \%$, moisture content was $7.96 \pm 0.60 \%$, ash content was $4.73 \pm 0.54$ and the total of nitrogen content was $12.39 \pm 0.08$. End post-rigour phase YSFP had statistically significant higher values in the total nitrogen content and protein content while lower lipid content from the raw material based on descriptive statistics. This indicated that fish peptones are efficient to be used as a bacteria substrate in media.

These results were higher than the previous study by Saputra (2008) and Saputra and Nurhayati (2013) who reported that peptones produced from the post-rigour Yellowstripe scad fish, had a protein content of $81.50 \pm 0.19 \%$; a lipid content of $0.09 \pm 0.00 \%$ and a total nitrogen content of $11.86 \pm 0.04 \%$. However, the results were in the agreement with the results by Muzaifa et al. 
(2012). Based on the results by Muzaifa et al. (2012), the fish protein hydrolysate hydrolysed with Alcalase enzyme had a protein content of $82.66 \pm 1.36 \%$ and a lipid content of $0.87 \pm 0.18 \%$. While the fish protein hydrolysate hydrolysed with flavour enzyme had a protein content of $73.51 \pm 3.53 \%$ and a lipid content of $0.44 \pm 0.51 \%$ (Muzaifa et al., 2012). Fallah et al. (2015) also reported the protein content of the silver carp hydrolysate hydrolysed with Alcalase enzyme was higher $(92.92 \pm 0.18 \%)$ on a dry mass basis.

Table 2. Chemical composition of the end post-rigour phase YSFP

\begin{tabular}{lc}
\hline Proximate composition & *Values (\%) \\
\hline Moisture & $7.96 \pm 0.60$ \\
Ash & $4.73 \pm 0.54$ \\
Lipid & $0.07 \pm 0.01$ \\
Protein & $83.62 \pm 1.05$ \\
Total nitrogen content & $12.39 \pm 0.08$ \\
\hline
\end{tabular}

* Values (means) are expressed as a percentage $\left(\mathrm{g} .100 \mathrm{~g}^{-1}\right)$ on a wet mass basis.

In comparison to the total nitrogen content of the Yellowfin tuna heads hydrolysate hydrolysed with Alcalase and Prot Novozymes which were $12.84 \pm 2.33 \%$ and $11.68 \pm 1.03 \%$ respectively, the total nitrogen content of the end post-rigour phase YSFP were similar.

\subsection{Effect of $\mathrm{pH}$ on the enzymatic hydrolysis}

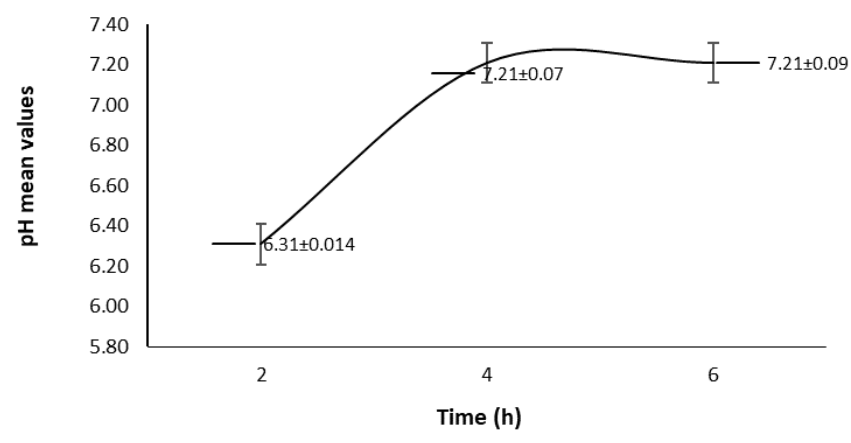

Figure 2. $\mathrm{pH}$ values of end post-rigour phase Yellowstripe scad fish hydrolysate. Values are expressed as mean \pm SD.

There are several factors that can influence the enzymatic hydrolysis namely $\mathrm{pH}$, time, the concentration of enzyme, and temperature. The $\mathrm{pH}$ of the homogenized end post-rigour phase Yellowstripe scad fish was suitable for the optimum hydrolysis activity of the papain enzyme, which varies between $6.31 \pm 0.014$ to $7.21 \pm 0.09$ (Figure 2). There was no significant change in the $\mathrm{pH}$ values during the process. Similarly, Bhaskar and Mahendrakar (2008) reported the $\mathrm{pH}$ values of the homogenized visceral mass and heat-treated visceral mass (HTVM) were $6.2 \pm 0.15$ and $5.95 \pm 0.10$ respectively. Yin et al. (2008) also reported that the protein solubility of Hemp Protein Isolates (HPI) was minimal at the $\mathrm{pH}$ range of $4.0-6.0$ but increased drastically as the $\mathrm{pH}$ changed to 3.0 or 7.0 . At the $\mathrm{pH}$ above 7.0, there was an insignificant difference level among different $\mathrm{pH}$ values at $(\mathrm{p}<0.05)$ for various hydrolysates with a degree of about $2.3-6.7 \%$. The research by Souissi et al. (2007) also reported that the $\mathrm{pH}$ value ranges from 6.0 to 10.0 to achieve a high degree of hydrolysis on fish protein hydrolysates.

\subsection{Amino acids analysis}

The quality of the end post-rigour phase YSFP was determined based on amino acids contains. The amino acid composition of end post-rigour phase YSFP has an important role in the growth of bacteria, due to the nitrogen sources used in the bacteria's growth activity. Amino acids composition in fish peptones variated and generally depends on several factors such as raw material, enzyme source, and hydrolysis condition (Klompong, Benjakul, Kantachote et al., 2009; Klompong, Benjakul, Yachai et al., 2009). Amino acids composition of the end post-rigour phase YFSP is shown in Table 3.

Table 3 shows the amino acid composition (g. $100 \mathrm{~g}^{-1}$ protein) of the end post-rigour phase YSFP, post-rigour Yellowstripe scad fish peptone, and two types of bacto peptones (Oxoid and Difco) used as standard. The end post-rigour phase YSFP contained nine essential amino acids namely phenylalanine, isoleucine, lysine, histidine, leucine, methionine, threonine, valine, arginine. Besides the essential amino acids, it also contained non-essential amino acids namely alanine, aspartic acid, glutamic acid, cysteine, tyrosine, glycine, proline, and serine.

These results were similar to the post-rigour Yellowstripe scad fish peptones which contained the essential and non-essential amino acids as reported by Saputra (2008) and Saputra and Nurhayati (2013). This result was also similar to the result obtained by Seniman et al. (2014) that reported catfish protein hydrolysates to have all essential amino acids and non-essential amino acids.

In this study (Table 3), the end post-rigour phase YSFP contained more glutamic acid (10.43 g.100 g $\mathrm{g}^{-1}$ protein), aspartic acid (5.92 g.100 $\mathrm{g}^{-1}$ protein) and histidine (4.12 g.100 g $\mathrm{g}^{-1}$ protein). The studies conducted by Saputra (2008) and Saputra and Nurhayati (2013) found that the glutamic acid (10.18 g.100 g $\mathrm{g}^{-1}$ protein), aspartic acid (6.50 g. $100 \mathrm{~g}^{-1}$ protein) and histidine ( $4.70 \mathrm{~g}$ $100 \mathrm{~g}^{-1}$ protein). These amino acids were higher compared to other amino acids. Seniman et al. (2014); Ghassem et al. (2014); and Hou et al. (2011) also reported that glutamic acid and aspartic acid were higher levels than those of other peptones as compared. 
Table 3. Amino acid composition (g. $100 \mathrm{~g}^{-1}$ protein) of commercial bacto peptones, post-rigour Yellowstripe scad fish peptones and end post-rigour phase Yellowstripe scad fish peptones.

\begin{tabular}{|c|c|c|c|c|}
\hline \multirow[b]{2}{*}{ Amino acid } & \multicolumn{4}{|c|}{ Average of amino acid composition (\%) } \\
\hline & Difco peptones* & Oxoid peptones ${ }^{* *}$ & $\begin{array}{l}\text { Post-rigour Yellowstripe } \\
\text { scad fish peptones } * * *\end{array}$ & $\begin{array}{c}\text { End post-rigour phase } \\
\text { Yellowstripe scad fish peptones }\end{array}$ \\
\hline Histidine & 0.8 & 1.5 & 4.7 & 4.12 \\
\hline Isoleucine & 2.1 & 2.4 & 1.33 & 0.96 \\
\hline Leucine & 3.8 & 5 & 4.76 & 2.42 \\
\hline Lysine & 3.4 & 5.8 & 2.76 & 2.25 \\
\hline Methionine & 0.7 & 1.4 & 4.01 & 3.07 \\
\hline Phenylalanine & 2.8 & 2.3 & 2.17 & 1.68 \\
\hline Threonine & 1.1 & 2.6 & 1.25 & 1.06 \\
\hline Valine & 2.8 & 3.6 & 3.82 & 2.61 \\
\hline Arginine & 5.8 & 8.6 & 1.45 & 2.85 \\
\hline Alanine & 9.2 & 7 & 0.74 & 0.55 \\
\hline Aspartic acid & 5 & 7.5 & 6.5 & 5.92 \\
\hline Glutamic acid & 8.1 & 11.6 & 10.18 & 10.43 \\
\hline Cysteine & - & 0.5 & 1.6 & 0.65 \\
\hline Tyrosine & 0.6 & 1.8 & 1.45 & 1.32 \\
\hline Glycine & 15.9 & 5.6 & 1.04 & 0.96 \\
\hline Proline & 8.8 & - & 1.8 & 1.49 \\
\hline Serine & 1.5 & 2.9 & 2.88 & 2.93 \\
\hline
\end{tabular}

***Bionutrient Technical Manual (2006); ***Saputra (2008); Saputra and Nurhayati (2013)

Table 4. Characteristics of the commercial bacto peptones, post-rigour Yellowstripe scad fish peptones and end post-rigour phase Yellowstripe scad fish peptones.

\begin{tabular}{lccc}
\hline \multicolumn{1}{c}{ Characteristics } & Bacto peptones $(\%)^{*}$ & $\begin{array}{c}\text { Yellowstripe scad fish } \\
\text { peptones on post rigor }(\%)^{* *}\end{array}$ & $\begin{array}{c}\text { Yellowstripe scad fish peptones } \\
\text { on End post-rigour }(\%)\end{array}$ \\
\hline Solubility in water & 100 & 96.74 & 97.08 \\
Total Nitrogen $(\mathrm{TN})$ & $12-13$ & 11.86 & 12.39 \\
$\alpha$-amino Nitrogen $(\alpha / \mathrm{N})$ & $1.2-2.5$ & 1.07 & 1.03 \\
$(\alpha / \mathrm{N}) / \mathrm{TN}$ & $11-21$ & 9.02 & 8.31 \\
Salinity & $\leq 17$ & 0.41 & 4.19 \\
\hline
\end{tabular}

*Bionutrient Technical Manual (2006); **Saputra and Nurhayati (2013)

3.5 Characterization of the end post-rigour phase Yellowstripe scad fish

Generally, some products produced had standard properties, including the end post-rigour phase YSFP. The dry product was determined and compared with those of the post-rigour peptones and the commercial peptones used as standard can be seen in Table 4.

From the results, the total nitrogen (TN) content, $\alpha /$ $\mathrm{N}$, the ratio of $\alpha / \mathrm{N}$ per $\mathrm{TN}$, the salinity and the water solubility of end post-rigour phase YSFP were $12.39 \%$, $1.03 \%, 8.31 \%, 4.19$ and $97.08 \%$ respectively. From the results, the YSFP had the same better characteristics with the previous study reported by Nurhayati et al. (2015), especially the higher total nitrogen content. This indicated that the quality of the end post-rigour phase YSFP was capable of supporting the bacteria's growth due to the high free amino acids.

Research by Vaseliva-Tonkova et al. (2007) reported that some of the properties of the dry products of Eladin and blood hydrolysates have better characteristics than the standard especially higher amino nitrogen/total nitrogen ratio that was about $65.30 \%$ and $68.10 \%$ respectively. A similar study was also reported by Suhandana (2010) that stated that peptones were produced from tuna viscera had a solubility of $98.20 \%$; TN content of $8.03 \%$; free $\alpha / \mathrm{N}$ of $1.12 \%$; a ratio $\alpha / \mathrm{N}$ per TN of $13.93 \%$; with salt content of $0.79 \%$. The characteristics of the end post-rigour phase YSFP were similar to the study by Nurhayati et al. (2015) that hydrolysed by-catch fish with $0.3 \%$ papain enzyme for 5 hours which produced hydrolysate with a protein content of $71.39 \%$, solubility of $99.96 \%$, TN content of $11.42 \%$, $\alpha / \mathrm{N}$ of $1.76 \%$, ratio of $\alpha / \mathrm{N}$ per $\mathrm{TN}$ of $15.41 \%$, and salinity of $7.82 \%$.

\subsection{Microbial growth application}

In this work, the growth curves of Bacillus spp., $S$. 
aureus and E. coli are shown in Figure 3, 4, and 5 respectively. As can be seen from Figure 3, the growth rate of Bacillus spp. on the test peptones media from 0-2 hrs was stable in the lag phase. The exponential growth of Bacillus spp. happened from 4-16 hrs on the tested media. The best growth rate was observed on the medium containing end post-rigour phase YSFP although there was no significant difference with the medium containing post-rigour Yellowstripe scad fish peptone. Saputra (2008) and Saputra and Nurhayati (2013) reported that the growth of Bacillus spp. on postrigour Yellowstripe scad fish peptone was higher than the bacto peptone. The better performance of fish peptone in comparison with commercial media was also reported in other researches (Poernomo and Buckle, 2002; Vieira et al., 2005; Safari et al., 2011; Safari et al., 2012).

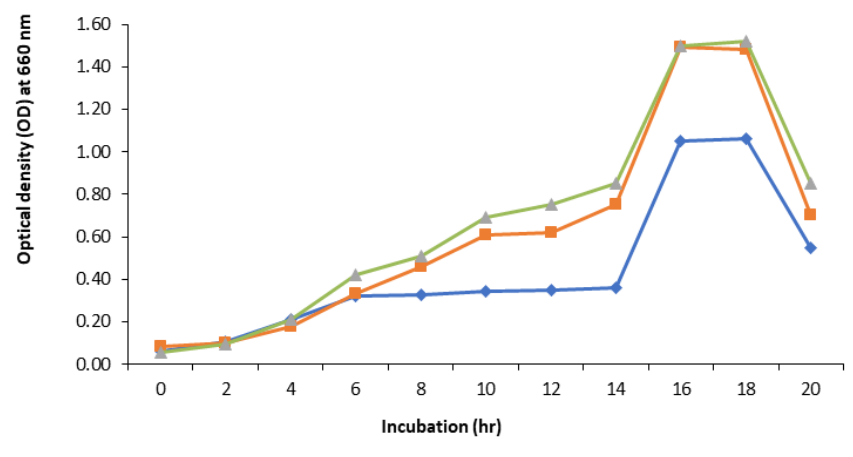

Figure 3. Growth of Bacillus spp. in test media

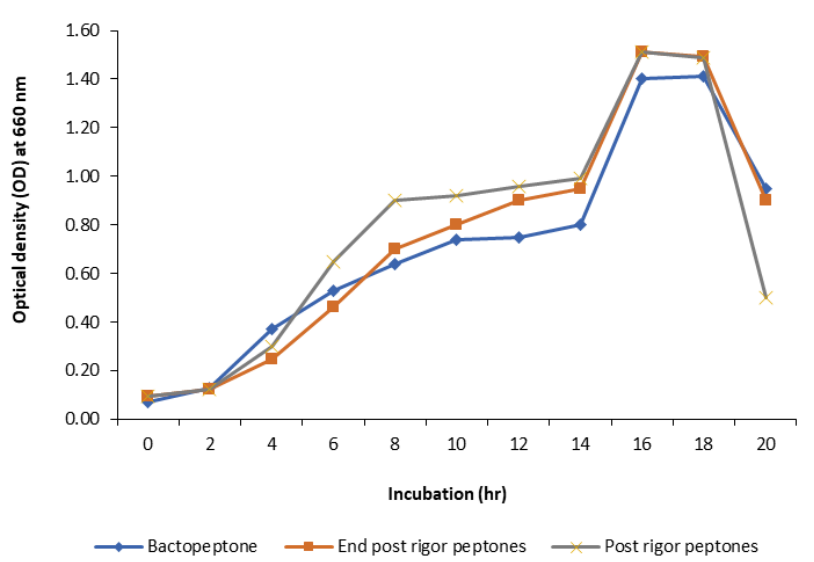

Figure 4. Growth of $S$. aureus in test media

The growth rate for $S$. aureus (Figure 4) was similar to the growth rate of Bacillus spp. on the microbial growth application. As shown in Figure 4, the lag phase of $S$. aureus was shorter, similar to Bacillus spp. (0-2 $\mathrm{hrs}$ ). The exponential phase happened at $10 \mathrm{hrs}$ (from 4 hrs to $14 \mathrm{hrs}$ ) for all the tested media. As shown in Figure 4, the growth rate of $S$. aureus on the end postrigour phase YSFP medium was better compared to other media. Similarly, Nurhayati et al. (2015) reported that the lag phase of for $S$. aureus on peptone from spoiled by -catch fish was shorter (0-2 hrs), and the exponential phase was at $12 \mathrm{hrs}$ (from $2 \mathrm{hrs}$ to $14 \mathrm{hrs}$ ).

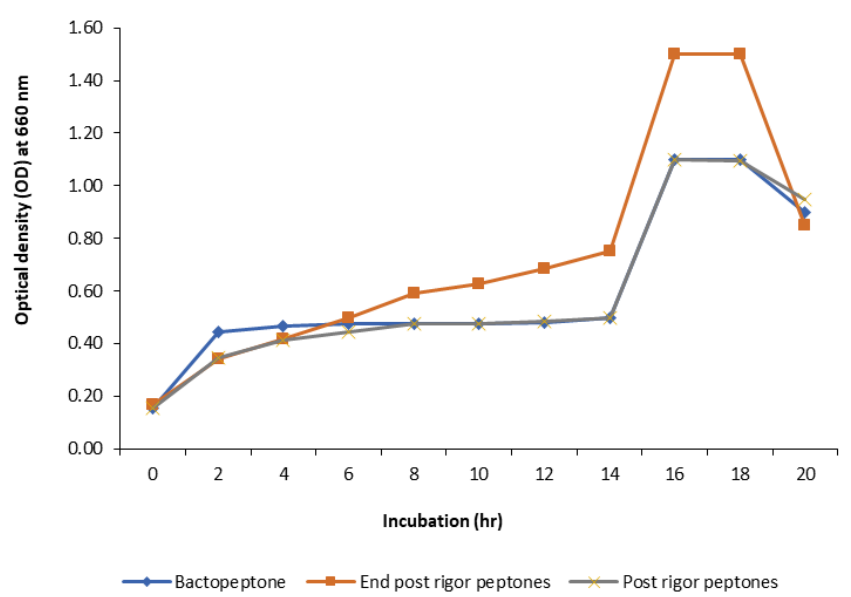

Figure 5. Growth of E. coli in test media

E. coli also showed similar growth rate compared to S. aureus and Bacillus spp. (Figure 5). The lag phase of E. coli was shorter, and the exponential phase was at 10 hrs (from $4 \mathrm{hrs}$ to $14 \mathrm{hrs}$ ) for all the tested media. As shown in Figures 3, 4 and 5, better results were obtained from the end post-rigour phase YSFP for all bacteria tested. This may be due to end post-rigour phase YSFP contained short peptides, available free amino acids as nitrogen resources for bacteria's growth.

\section{Conclusion}

The Yellowstripe scad fish on the end post-rigour phase with a high protein content of $15.47 \%$ and low lipid content of $2.94 \%$ had the potential as the raw material to produce fish peptones. The optimum enzyme concentration was $0.20 \%$ and the hydrolysis process should be carried out at $60^{\circ} \mathrm{C}$ for $6 \mathrm{hrs}$. The end postrigour phase YFSP contained nine essential amino acids and eight non-essential amino acids. The end post-rigour phase YFSP were also rich in glutamic acid (10.43 g.100 $\mathrm{g}^{-1}$ protein), aspartic acids (5.92 g.100 $\mathrm{g}^{-1}$ protein) and histidine (4.12 g.100 g $\mathrm{g}^{-1}$ protein). The characteristics of the end post-rigour phase YFSP were better than postrigour Yellowstripe scad fish peptone and commercially available bacto peptone including enhancing the microbial growth in bacteria medium.

\section{Conflict of Interest}

The authors declared no conflict of interest.

\section{Acknowledgements}

The authors would like to acknowledge funding of this research, provided by the Research Grant of the Directorate General of Higher Education, Ministry of Education and Culture of Republic of Indonesia (on behalf of Dede Saputra). 


\section{References}

AOAC (Association of Official Analytical Chemists). (1995). Official Method of Analysis. $16^{\text {th }}$ ed. Washington DC, USA: The Association of Official Analytical Chemists.

AOAC (Association of Official Analytical Chemists). (2000). Official Methods of Analysis. Gaithersburg: Association of Agricultural Chemists.

AOAC (Association of Official Analytical Chemists). (2005). Official Method of Analysis. $16^{\text {th }}$ ed. Washington DC, USA: The Association of Official Analytical Chemists.

KKP (Kementerian Kelautan dan Perikanan). (2011). Statistik Perikanan Tangkap Indonesia. Jakarta, Indonesia: Direktorat Jenderal Perikanan Tangkap. [In Bahasa Indonesia].

Bhaskar, N. and Mahendrakar, N. (2008). Protein hydrolysate from visceral waste proteins of Catla (Catla catla): Optimization of hydrolysis conditions for a commercial neutral protease. Journal of Bioresource Technology, 99(10), 4105-4111. https:// doi.org/10.1016/j.biortech.2007.09.006

Bionutrient Technical Manual. (2010). Retrieved from BD Medical Technology websited: http://bd.com

Fallah, M., Bahram, S. and Javadian, S. (2015). Fish peptone development using enzymatic hydrolysis of silver carp by-products as a nitrogen source in Staphylococcus aureus media. Food Science and Nutrition, 3(2), 153-157. https://doi.org/10.1002/ fsn 3.198

Ghassem, M., Fern, S.S., Said, M., Ali, Z.M., Ibrahim, S. and Babji, A.S. (2014). Kinetic characterization of Channa striatus muscle sarcoplasmic and myofibrillar protein hydrolysates. Journal of Food Science and Technology, 51(3), 467-475. https:// doi.org/10.1007/s13197-011-0526-6

Green, J., Paskell, S. and Goldmintz, D. (1977). Fish peptones for microbial media developed from red hake and from a fishery by-product. Journal of Food Protection, 40, 181-186. https:// doi.org/10.4315/0362-028X-40.3.181

Herzog, M.H., Francis, G. and Clarke. (2019). A Understanding Statistics and Experimental Design: How To Not Lie With Statistics: Learning Materials In Biosciences. Switzerland: Springer. https:// doi.org/10.1007/978-3-030-03499-3

Hou, H., Li, B. and Zhao, X. (2011). Enzymatic hydrolysis of defatted mackerel protein with low bitter taste. Journal of Ocean Uni. China, 10(1), 8592. https://doi.org/10.1007/s11802-011-1785-6

Klompong, V., Benjakul, S., Kantachote, D. and Shahidi, F. (2009). Characteristics and use of Yellowstripe
Trevally hydrolysate as culture media. Journal of Food Science, 74(6), S219-S225. https:// doi.org/10.1111/j.1750-3841.2009.01213.x

Klompong, V., Benjakul, S., Yachai, M., Visessanguan, W., Shahidi, F. and Hayes, K. (2009). Amino acid composition and antioxidative peptides from protein hydrolysates of Yellowstripe trevally (Selaroides leptolepis). Journal of Food Science, 74(2), C126C133.

3841.2009.01047.x

Kristinsson, H. and Rasco, B. (2000). Fish protein hydrolysates: production, biochemical, and functional properties. Journal of Food Science and Nutrition, 1(40), 43-81. https:// doi.org/10.1080/10408690091189266

Muzaifa, M., Safriani, N. and Zakaria, F. (2012). Production of protein hydrolysates from fish byproduct prepared by enzymic hydrolysis. Aquaculture, Aquarium, Conservation and Legislation International Journal of the Bioflux Society, 5(1), 36-39.

Nurhayati, T., Ibrahim, B., Suptijah, P., Salamah, E., Fitra, R.N. and Astuti, E.R.W. (2015). Karakterisasi pepton ikan hasil tangkap sampingan tidak layak konsumsi sebagai sumber nutrien pertumbuhan mikroorganisme. Jurnal Teknologi Industri Pertanian, 25(1), 68-77. [In Bahasa Indonesia].

Poernomo, A. and Buckle, K. (2002). Crude peptones from cowtail ray (Trygon sephen) viscera as microbial growth media. World Journal of Microbiology and Biotechnology, 18, 333-340.

Rahayuningsih, M. and Wiranti, N.G. (2014). Process design of peptone production from peanut meal as by product of oil industry using crude papain. The ASEAN Conference on Science and Technology, Bogor, 2014. Jakarta, JKT: LIPI Press.

Safari, R., Saravi, H.N., Pourgholam, R., Motalebi, A.A. and Ghoroghi, A. (2011). Use of hydrolysates from silver carp (Hypophthalmichthys molitrix) head as peptone for Vibrio anguillarum and optimization using response surface method (RSM). Journal of Aquatic Food Production Technology, 20(2), 247257. https://doi.org/10.1080/10498850.2011.562064

Saputra, D. (2008). Pembuatan Pepton Ikan Selar (Caranx leptolepis) Hasil Tangkap Sampingan (HTS) pada Kondisi Post Rigor dan Busuk [skripsi]. Bogor: Fakultas Perikanan dan Ilmu Kelautan, Institut Pertanian Bogor. [In Bahasa Indonesia].

Saputra, D. and Nurhayati, T. (2013). Produksi dan aplikasi pepton ikan selar untuk media pertumbuhan bakteri. Jurnal Pengolahan Hasil Perikanan Indonesia, 6, 215-223. [In Bahasa Indonesia]. 
Seniman, M.S., Yusop, S.M. and Babji, A.S. (2014). Biochemical properties and proximate composition of catfish enzymatic protein hydrolysates made using subtilisin. International Journal Technical Research and Applications, 2(2), 15-19.

Souissi, N., Bougatef, A., Triki-Ellouz, Y. and Nasri, M. (2007). Biochemical and functional properties of Sardinelle (Sardinella aurita) by-product hydrolysates. Food Technology and Biotechnology, 45(2), 187-194.

Suhandana, M. (2010). Pemanfaatan jeroan ikan tongkol sebagai bahan baku pembuatan pepton secara enzimatis.[skripsi]. Bogor: Teknologi Hasil Perairan, Institut Pertanian Bogor. [In Bahasa Indonesia].

United States Department of Agriculture (USDA) Food Safety and Inspection Service (FSIS) (2009). Determination of salt. Retrieved on October 17, 2017 from FSIS Website: https://www.fsis.usda.gov/wps/ $\mathrm{wcm} /$ connect/b477e0ba-d7a8-4cf2-b42db9b284a285a6/CLG_SLT_03.pdf?MOD=AJPERES

Vaseliva-Tonkova, E., Nustorova, M. and Gushterova, A. (2007). New protein hydrolysates from collagen wastes used as peptones for bacterial growth. Current Microbiology, 54(1), 54-57. https:// doi.org/10.1007/s00284-006-0308-y

Vieira, G.H., Vieira, R.H., Macrae, A. and Sousa, O.V. (2005). Peptone preparation from fishing byproducts. Journal of the Science of Food and Agriculture, 85(7), 1235-1237. https:// doi.org/10.1002/jsfa.2161

Voight Global Distribution Inc. (2019). Bacto Peptone $211677500 \mathrm{~g}$. Retrieved August 23, 2019, from FGD Inc. Website: https:/voigtglobal.com/search? controller $=$ search\&orderby $=$ position\&orderway $=$ des c\&search_query $=$ Bacto + Peptone $+211677+500 \mathrm{~g} \& s u$ bmit_search $=$ Search

Yin, S., Chuan-He, T., Jin-Song, C., Er-Kun, H., QiBiao, W. and Xiao-Quan, Y. (2008). Effects of limited enzymatic hydrolysis with trypsin on the functional properties of hemp (Cannabis. L) protein isolate. Food Chemistry, 106(3), 1004-1013. https:// doi.org/10.1016/j.foodchem.2007.07.030 